\title{
PENGATURAN TINDAK PIDANA PERJUDIAN DAN PERTANGGUNGJAWBAN PIDANA KORPORASI DALAM MICRO-TRANSACTION PADA GAME ONLINE
}

\author{
I Gede Darma Sannyasa, Advocates \& Legal Consultants Dr. I Nyoman Sujana, \\ SH.,MH. \& Partners, e-mail: dedesannyasa@gmail.com \\ I Ketut Mertha, Fakultas Hukum Universitas Udayana, e-mail: \\ ketut.mertha46@gmail.com
}

doi: https:// doi.org/10.24843/KS.2020.v08.i09.p14

\begin{abstract}
ABSTRAK
Tujuan studi ini dilakukan guna mengkaji delik perjudian pada micro-transaction dalam game online serta bentuk pertanggungjawaban pidana Korporasi sebagai penyedia layanan perjudian microtransaction dalam game online. Metode penelitian hukum normatif dengan pendekatan perundangundangan dan konseptual, digunakan pada studi ini. Hasil studi menunjukkan Microtransaction dalam game online baik dalam bentuk gacha atau lootbox mengandung unsur tindak pidana perjudian dan mengenai perjudian sendiri telah diatur dalam KUHP, Undang-undang Penertiban Perjudian serta melalui Peraturan Pemerintah tentang Pelaksanaan Penertiban Perjudian dan oleh karena perjudian ini dilakukan secara virtual maka Undang-undang Informasi dan Transaksi Elektronik menjadi lex specialis pada micro-transaction dalam game online. Kemudian Publisher dan/atau developer game merupakan Korporasi yang juga sebagai subyek hukum pidana dan menjadi pihak yang menyediakan sarana perjudian dengan bentuk Microtransaction dalam game online baik berupa gacha dan loot box, sehingga atas hal tersebut Publisher dan/atau developer game dapat dimintai pertanggungjawaban pidana.
\end{abstract}

Kata Kunci: Micro-transaction dalam game online, Perjudian Online, Pertanggungjawaban Korporasi.

\begin{abstract}
The purpose of this study is to examine the offense of gambling on micro-transactions in the online game as well as the form of corporate criminal liability as a provider of micro-transaction gambling services in the online game. The normative legal research method with a statutory and conceptual approach is used in this study. The study results show that microtransaction in online games both in the form of gacha or lootbox contains elements of gambling crime and regarding gambling itself has been regulated in the Criminal Code, the Gambling Control Act and through the Government Regulation on the Implementation of Gambling Control and because of this gambling is done virtually invite Information and Electronic Transactions to be lex specialists on in-online game micro-transactions. Then the Publisher and / or game developer is a corporation that is also a subject of criminal law and becomes a party that provides gambling facilities in the form of microtransaction in the online game in the form of gacha and loot box, so that the Publisher and / or game developer can be held liable for criminal liability.
\end{abstract}

Key Words: Micro-transaction in the online game, Online Gambling, Audiobook Access, Corporate Liability. 


\section{Pendahuluan}

\subsection{Latar Belakang Masalah}

Hidup dengan tentram, aman, damai, bahagia, sejahtera secara lahir maupun batin menjadi hak yang dimiliki setiap orang. Kurang lebih begitulah gambaran hak untuk hidup yang diatur oleh Undang-Undang Hak Asasi Manusia untuk memberikan jaminan atas kebebasan dasar manusia. Hidup yang bahagia bagi masyarakatnya menjadi cita-cita suatu negara, dan kebahagian salah satunya dapat diperoleh melalui adanya hiburan. Hiburan sendiri dapat berbentuk berbagai macam diantaranya sirkus, teater musical, pentas seni, komedi, olahraga, konser dan yang sedang marak adalah video game. Video game sendiri dari pandangan Mifflin merupakan bentuk permainan yang dimainkan dengan cara melawan responden lain dan/atau dengan melawan sistem komputer. ${ }^{1}$ Selain itu video game dimainkan dengan menggunakan kombinasi perangkat televisi atau media display monitor sebagai media visual dan console sebagai tempat atau media penerjemah dari kaset atau compact disc (CD). Video game sendiri memiliki berbagai macam genre diantaranya game role playing, puzzle, fighting (pertarungan),aksi-shooting, simulasi, petualangan, simulasi kendaraan strategi, serta olahraga dan lainnya.

Game atau video game menurut Oxford Dictionaries adalah "a game played by electronically manipulated images produced by a computer program on monitor or other display". ${ }^{2}$ Menurut Kirriemuir dan McFarlane, digital game/video game adalah sesuatu yang menyediakan informasi digital dalam wujud visual kepada seorang pemain atau lebih, untuk menerima masukan data dari pemain, memproses data sesuai yang telah diprogram dan mengubah infomasi digital yang disesuaikan untuk pemain. ${ }^{3}$ Seiring perkembangan teknologi game tidak saja dapat dimainkan sendiri atau dengan orang yang bermain dengan perangkat yang sama, namun dapat diaminkan secara online tidak terbatas pada ruang dan waktu yang dikenal dengan game online. Game yang dimainkan secara online membuat persaingan antar pemain semakin kompetitip dan cenderung liar. Sikap alami manusia yang ingin bersaing dan ingin menjadi yang terbaik dimanfaatkan oleh develover maupun publisher game untuk memberikan kesempatan kepada pemain untuk melakukan transaksi untuk dapat memperoleh sesuatu yang diinginkan dalam game. Transaksi dalam game inilah yang kemudian dikenal dengan micro-transaction. Micro-transaction atau transaksi mikro atau yang disingkat MTX, adalah bentuk bisnis jual beli dimana penggunanya dapat membeli barang virtual yang dikehendaki. Micro-transaction merupakan bentuk transaksi keuangan kecil yang dilakukan secara online. ${ }^{4}$ Transaksi merupakan suatu peristiwa hukum antara penjual dan pembeli yang dewasai tidak hanya dapat dilakukan secara berhadapan, melainkan dapat dilakukan dengan penjual dan pembeli

1 Indahtiningrum, Fitriana. "Hubungan antara kecanduan video game dengan stres pada mahasiswa Universitas Surabaya." Calyptra 2, no. 1 (2013): 1-17.

2 Lexico, https://www.lexico.com/en/definition/video_game. Diakses pada tanggal 12 Pebruari 2020.

3 Suangga, Anisa. "Hubungan Aktivitas Bermain Video Game dengan School Myopia pada Siswa-Siswi SD Asy Syifa 1 Bandung." Students e-Journal 1, no. 1 (2012): 36.

4 Garvin, Garvin, Jennifer Claudia, and Irene Evita. "MICRO TRANSACTION DALAM ONLINE GAME: APAKAH MEMICU PERILAKU BELANJA ONLINE YANG BERMASALAH?." PSYCHE: Jurnal Psikologi 1, no. 2 (2019): 46-54. 
dalam keadaan terpisah. ${ }^{5}$ Artinya antara penjual dan pembeli tidak berhadap-hadapan secara langsung melainkan melakukan perbuatan jual beli melalui media elektronik yang dihubungkan dengan jaringan internet.

Seiring perkembangan micro-transaction pada game ini, terdapat beberapa jenis micro-transaction, yaitu gacha dan loot box. Gacha dan loot box merupakan mekanisme micro-transactionpada game dimana player membeli menggunakan uang asli untuk mendapatkan barang virtual dan/atau item yang menarik atau bermanfaat dalam game. Gacha dan loot boxmodel ini semakin berkembang, player memperoleh bermacam-macam barang virtual atau item secara acak. Konsep di balik loot box yang telah diperoleh tersebut adalah bahwa, meskipun mendapatkan lebih banyak item dengan harga tertentu dalam loot box yang telah dibeli, pemain mungkin tidak menginginkan item-item itu, dan akhirnya terus tertarik untuk mendapatkan dan/atau membeli item yang sama beberapa kali, sampai mendapatkan item yang diinginkan. Alih-alih pembelian satu kali untuk barang yang diinginkan, pengguna digiring untuk terus membeli beberapa loot box. Sistem transaksi micro-transaction pada game ini tidak serta merta memberikan apa yang player inginkan setelah dibeli, melainkan ada suatu proses pengacakan terhadap sesuatu yang telah dibeli yang merangsang player untuk mencoba lagi dan/atau membeli lagi.

Sistem yang demikian dapat disamakan dengan suatu lottre yang mana seseorang di influen untuk terus membeli dan mencoba dengan mengandalkan peruntungan, karena seseorang tersebut belum tentu mendapat apa yang diinginkan. Adanya micro-transaction yang demikian dalam game khususnya game online, membuat pengaruh yang kurang baik bagi para player game baik dewasa, remaja dan tidak terkecuali anak-anak. Seperti contoh peristiwa yang diberitakan Kompas, dimana seorang Ibu di Kediri Kaget Dapat Tagihan Game Online Rp. 11 Juta, ${ }^{6}$ selain itu sebagaimana peristiwa yang diberitakan Tempo, yaitu Dapat Tagiihan Game Onlline Rp. 65 Juta, Inul Daratista Kejang7, dan masih banyak lagi peristiwa serupa yang diberitakan media maupun yang tidak terekspos media.

Kasus terbaru berkaitan dengan microtransaction pada game tersebut adalah sebagaimana diberitakan media kenamaan Prancis, L'Equipe, bahwa dua orang pengacara asal Prancis yaitu Karim Morand-Lahouazi dan Victor Zagury telah menggugat Electronic Arts (EA) salah satu developer game karena salah satu game besutan EA tersebut yakni FIFA 20 pada mode FIFA Ultimate Team menyediakan sebuah sarana perjudian. ${ }^{8}$ Dua pengacara tersebut diberitakan mewakili beberapa player yang merasa dirugikan lantaran satu-satunya cara untuk menang dalam mode FIFA Ultimate Team tersebut adalah dengan melakukan microtransaction dengan uang sungguhan untuk kemudian mendapatkan pemain yang diinginkan dalam bentuk lootbox (gacha). Lebih lanjut dikatakan bahwa para pemain game yang melakukan

5 ARIEF, MOH ZAINOL, and SUTRISNI SUTRISNI. "Perbuatan Melawan Hukum dalam Transaksi Jual-beli melalui Internet Ditinjau dari Buku III Kuhperdata." Jendela Hukum 1, no. 2 (2014): 135649.

6 Kompas.com, Cerita Ibu di Kediri Kaget Dapat Tagihan Game Online Rp. 11 Juta,https://regional.kompas.com/read/2019/04/10/12362821/cerita-ibu--di-kedirikaget--dapat--tagihan--game--online--rp--11--juta. Diakses pada tanggal 12 Pebruari 2020.

7 Tempo.co, Dapat Tagiihan Game Onlline Rp 65 Juta, Inul Daratista Kejang, https://www.msn.com/id-id/hiburan/celebrity/dapat--tagiihan--game--onlline-rp--65juta--inul--daratista-kejang/ar-BBXMUhf. Diakses pada tanggal 12 Pebruari 2020.

8 Heri Susanto, (2020). Menohok! Pengacara Prancis Gugat Game FIFA 20, Kenapa? Vivagoal, diakses pada 3 Maret 2020, pukul 09.45 WITA. 
microtransaction dalam bentuk lootbox, belum tentu mendapatkan apa yang diinginkan oleh pemain yang bersangkutan dan hal tersebut merugikan bagi pemain. Indikasi perjudian yang digambarkan adalah ketika player semakin banyak membayar dalam microtransaction tersebut maka semakin besar kesempatan bagi player untuk mendapatkan sesuatu yang bagus, yang kemudian menciptakan sistem ilusi dan bersifat adiktif. Hal tersebut menunjukkan adanya skema pertaruhan dalam microtransaction ini.

Sistem yang demikian memicu pemain untuk melakukan dan melakukan kembali micro-transaction untuk mendapat sesuatu yang diinginkan untuk kemudian digunakan dan dipamerkan dalam suatu permainan game. Terdapat beberapa tulisan ilmiah yang memiliki keterkaitan dengan isu hukum diatas antara lain: Hendri Saputra Manalu yang membahas mengenai penegakan hukum terhadap pelaku tindak pidana perjudian online. ${ }^{9}$ Serta dalam karya ilmiah oleh Enik Isnaini yang membahas tinjauan yuridis normatif perjudian online menurut hukum positif di Indonesia. ${ }^{10}$ Berdasarkan beberapa tulisan jurnal terkait tindak pidana perjudian game online tersebut diatas, belum ada yang membahas mengenai perjudian pada micro-transaction dalam game online beserta pertanggungjawaban korporasi penyedia perjudian micro-transaction dalam game online tersebut. Hal tersebut karena micro-transaction dalam game online ini merupakan sesuatu hal yang baru, yang kemudian dimanfaatkan oleh pihak yang mengadakannya baik publisher/developer game untuk memperoleh keuntungan dari sistem tersebut. Untuk itu, menarik kiranya fenomena micro-transaction dalam game online tersebut untuk dikaji berdasarkan aspek hukum, khususnya melihat delik pidana perjudian dalam micro-transaction pada game online dan mengetahui pertanggungjawaban korporasi penyedia perjudian micro-transaction dalam game online.

\subsection{Rumusan Masalah}

Rumusan masalah pada jurnal ini membahas mengenai diantaranya:

1. Bagaimanakah ketentuan hukum pidana mengatur delik perjudian yang terdapat pada micro-transaction dalam game?

2. Bagaimanakah Pertanggungjawaban Pidana oleh Korporasi sebagai penyedia layanan perjudian micro-transaction dalam game online?

\subsection{Tujuan Penulisan}

Tujuan dari penulisan penelitian ini yakni agar dapat mengetahui delik perjudian pada micro-transaction dalam game serta bentuk pertanggungjawaban pidana Korporasi sebagai penyedia layanan perjudian micro-transaction dalam game.

\section{Metode Penelitian}

Suatu cara untuk menemukan kembali secara cermat dan meneliti data hukum atau bahan hukum guna menyelesaikan masalah-masalah hukum disebut sebagai penelitian hukum. ${ }^{11}$ Tujuan dari suatu penelitian hukum merupakan bentuk usaha

9 Manalu, Hendri Saputra. "Penegakan Hukum Terhadap Pelaku Tindak Pidana Perjudian Online." Journal of Education, Humaniora and Social Sciences (JEHSS) 2, no. 2 (2019): 428-539.

10 Isnaini, Enik. "TINJAUAN YURIDIS NORMATIF PERJUDIAN ONLINE MENURUT HUKUM POSITIF DI INDONESIA." Jurnal Independent 5, no. 1 (2017): 23-32.

11 Diantha, I.M.P. Metode Penelitian Hukum Normatif Dalam Justifikasi Teori Hukum (Jakarta, Prenada Media Group, 2017), 1. 
untuk mencari, menganalisa, mengkaji kebenaran ilmu pengetahuan terkait ilmu hukum. Metode penelitian yang digunakan pada jurnal ini yaitu metode penelitian hukum normatif. Pendekatan yang digunakan yaitu pendekatan perundangundangaan (statute apprroach) dan pendekatan konseptual (conceptual apprroach). Pendekatan perundang--undangan digunakan agar dapat menelaah semua aturanaturan hukum baik undang-undang atau regulasi yang berkaitan dengan isu hukum dalam jurnal. ${ }^{12}$ Serta pendekatan konseptual dimaksudkan untuk menganalisis teori hukum, konsep hukum, ataupun asas-asas hukum berkaitan dengan persoalan yang diangkat dalam jurnal.

\section{Hasil dan Pembahasan}

\subsection{Tindak Pidana Perjudian Pada Micro-Transaction Dalam Game}

Sistem microtransaction dalam video game, baik itu dalam bentuk gacha maupun lootbox menjadi daya tarik tersendiri keberadaannya dalam suatu game. Microtransaction menjadi jalan pintas bagi para player untuk untuk memperoleh sesuatu yang diinginkan pada game yang dimainkan. Namun masalahnya adalah bahwa para player tidak mengetahui apa yang bisa didapatkan setelah melakukan microtransaction dalam bentuk gacha maupun loot box tersebut. Lebih lanjut, kekhawatiran terjadi mengingat microtransaction pada game ini tidak saja dapat dilakukan oleh remaja, dewasa tetapi juga menyentuh anak-anak, dimana mereka cenderung mudah dipengaruhi untuk menghabiskan banyak uang hanya untuk bermain game. Melakukan transaksi yang mana pembeli tidak mengetahui apa yang didapat dari transaksi yang dilakukan, menunjukkan adanya unsur untung-untungan atau berdasarkan pada keberuntungan dalam membeli sesuatu pada game melalui microtransaction, membuat transaksi tersebut mencerminkan suatu bentuk perjudian. Dikatakan sebagai perjudian karena dalam sistem microtransaction tersebut pihak yang satu dipaksa mengikuti pola atau prosedur transaksi yang disediakan pihak lain, dan pihak yang ingin melakukan microtransaction hanya bergantung pada keberuntungan terhadap apa yang sudah dibeli dalam sistem microtransaction. Penting untuk diketahui, adanya suatu transaksi dengan pengharapan untuk menang, sifat untunguntungan yang memaksa pelakunya bergantung pada sesuatu yang bersifat untunguntungan atau spekulatif/kebetulan merupakan bentuk perbuatan perjudian. ${ }^{13}$

Kamus Besar Bahasa Indonesia mengartikan judi sebagai suatu permainan dengan taruhan uang atau barang berharga yang memiliki nilai. Yang diperjelas melalui berjudi yang diartikan sebagai sejumlah uang atau harta dipertaruhkan dalam tebakan-tebakan permainan yang bergantung pada kebetulan (keberuntungan), atas maksud memperoleh uang atau harta dengan nilai yang lebih besar daripada jumlah uang atau harta semulaa. Ironisnya, microtransaction pada game membuat seseorang membeli atau mendapatkan barang dalam bentuk virtual dengan tingkat keberlasilan memperoleh sesuatu tersebut yang tidak jelas, dengan uang asli.

Perjudian adalah salah satu bentuk permainan tertua yang ada di dunia, hampir seluruh negara di dunia mengenal permainan ini sebagai permainan yang bergantung

12 Marzuki, Peter Mahmud. Penelitian Hukum (Jakarta, Prenada Media Group, 2014), 133.

13 Waney, Geraldy. "Kajian Hukum terhadap Tindak Pidana Perjudian (Penerapan Pasal 303, 303 Bis Kuhp)." Lex Crimen 5, no. 3 (2016). 
pada sifat untung-untungan. ${ }^{14}$ Perjudian dalam bentuk apapun di Indonesia, pada hakekatnya merupakan kegiatan yang tidak sejalan dengan norma agama, norma kesusilan, dan ideologi negara yaitu Pancasila. Mental serta moral masyarakat sangat dirugikan tidak dikecualikan pula kalangan generasi muda, yang menunjukkan dampak negatif dari perjudian serta jika kepentingan nasional menjadi obyek tinjauannya, maka perjudian mencerminkan ancaman yang berbahaya bagi masyarakat, bangsa dan negara. Judi atau perjudian atau gamble dalam bahasa Inggris artinya, "play cards or other games for money, to risk money on a future event or possible happening, yang melibatkan para pemain atau disebut a gamester atau a gambler yaitu, one who plays cards or other games for money". ${ }^{15}$ Dalam buku "Patologi Sosial", oleh Kartini Kartono, menyebutkan perjudian yaitu suatu kegiatan dengan sengaja mempertaruhkan suatu nilai atau barang dan/atau sesuatu yang memiliki nilai dengan kesadaran akan risiko-risiko serta harapan-harapan tertentu dalam permainan, perlombaan, pertandingan dan kejadian-kejadian yang belum ada kepastian tentang hasilnya. ${ }^{16}$

Fenomena demikian menunjukkan perkembangan praktik perjudian yang tidak saja dilakukan sebagaimana judi konvensional yang biasa dikenal seperti judi kartu, judi tebakan dan banyak lagi lainnya, ${ }^{17}$ maupun judi online (daring) yang mulai marak terjadi di masyarakat, melainkan lebih berkembang lagi bahwa perjudian saat ini telah merambah dunia video game. Perjudian ini memberikan masalah bagi pelakunya dimana beberapa orang menjadi ketagihan, lalu beberapa orang tersebut tidak bisa berhenti berjudi yang pada akhirnya beberapa orang tersebut banyak kehilangan uang dan harta, artinya disamping diri sendirii dirugikan, masyarakat juga mengalami hal sama, hal tersebut karena selain meracuni jiwa seseorang, judi berpotensi memberi dampak buruk terhadap perekonomian masyarakat secara luas. ${ }^{18}$ Kerugian uang, kerugian mental serta mempengaruhi kesehatan merupakan dampak judi yang juga membuat pemainnya untuk menjadi seseorang pemalas yang akhirnya memperbesar kemungkinan para pemainnya melakukan tindakan yang melanggar hukum seperti mencuri, korupsi, dan bahkan membunuh.

Judi menjadi suatu permasalahan sosial karena dampaknya negatif bagi kepentingan nasional tidak terkecuali generasi muda. Dikenalnya judi oleh generasi muda membuatnya cenderung menjadi pemuda yang malas bekerja, secara serta merta membuat dana yang seharusnya bisa dikontribusikan guna pembangunan justru digunakan untuk permainan judi, padahal secara umum disadari bahwa judi adalah

14 Adnyana, Komang Wisnu, Putu Sugi Ardana, and I. Nyoman Lemes. "PEMIDANAAN TERHADAP PELAKU PERJUDIAN YANG DILAKUKAN ANAK-ANAK (STUDI KASUS DI PENGADILAN NEGERI SINGARAJA)." Kertha Widya 2, no. 2 (2019).

${ }^{15}$ West, Michael, An International Reader's Dictionaty, (London, Longman Group Limited, 1970), 155.

16 Haryadi, Wahyu Tris. "PENEGAKAN HUKUM JUDI ONLINE BERDASARKAN PENERAPAN KUHP DAN UNDANG UNDANG NO. 19 TAHUN 2016 TENTANG PERUBAHAN ATAS UNDANG-UNDANG NO. 11 TAHUN 2008 TENTANG INFORMASI DAN TRANSAKSI ELEKTRONIK." Jurnal Hukum Inrichting Recht Wahana Wacana Bidang Hukum 13, no. 2 (2019): 119-133.

17 Tuwo, Christy Prisilia Constantia. "Penerapan Pasal 303 Kitab Undang-undang Hukum Pidana Tentang Perjudian." Lex Crimen 5, no. 1 (2016).

18 Santoso, Eddy, and Sri Endah Wahyuningsih. "Peran Kepolisian Dalam Sistem Peradilan Pidana Terpadu Terhadap Penanggulangan Tindak Pidana Perjudian." Jurnal Daulat Hukum 1, no. 1 (2018). 
kegiatan yang tidak dibenarkan dalam agama, moral dan kesusialaan. Termasuk menjadi suatu penghambat dalam mencapai tujuan pembangunan nasional yaitu kesejahteraan masyarakat, karenanya perlu ditangani secara rasional dengan mengkaji penegakan hukum serta proses penindakan terhadap pelakunya. ${ }^{19}$ Perjudian dalam praktek dunia nyata dilakukan oleh pelaku, sedangkan dalam dunia cyber atau dalam sistem elektronik melakukan suatu perbuatan judi lebih praktis dikarenakan banyaknya tersedia media perjudian atau website perjudian dalam sistem elektronik dan juga untuk melakukannya tidak perlu untuk kumpul disuatu tempat pada waktu yang ditentukan, namun cukup dengan berada di depan media elektronik tertentu untuk bermain judi dengan dukungan jaringan internet. ${ }^{20}$

Sebagai suatu bentuk pelanggaran terhadap norma-norma yang ada dalam masyarakat, perjudian kemudian hukum positif di Indonesia diatur. Pasal 303 dan Pasal 303 bis dalam KUHP menjadi lex generalis mengenai perjudian dalam hukum pidana di Indonesia, yang pada perkembangannya diperbaharui/ dilengkapi dengan lex specialis dalam Undang-Undang No.7 tahun 1974 tentang Penertiban Perjudian serta Peraturan Pemerintah No.9 Tahun 1981 tentang Pelaksanaan Penertiban Perjudian. Diatur pada Pasal 303 ayat 3 KUHP, "Yang dikatakan main judi yakni tiap-tiap permainan berdasarkan harapan buat menang, umumnya mengandalkan untunguntungan saja serta kalau pengharapan itu jadi bertambah besar karena kepintaran dan kebiasaan pemain. Hal terhitung sebagai main judi yakni pertaruhan tentang keputusan perlombaan atau permainan lain, yang tidak diadakan oleh mereka yang turut berlomba atau main itu, demikian juga segala pertaruhan lainnya".

Sebelum tanggal 6 November 1974, ketentuan tentang perjudian diatur dalam Bab XIV, Buku II, Pasal 303 KUHP tentang Kejahatan dan Bab VI Buku III Pasal 543, tentang Pelanggaran. Pada tanggal 6 November 1974 Pemerintah telah mengesahkan Undang-Undang No. 7 tahun 1974 tentang Penertiban Perjudian, yang juga sebagai ketentuan yang memberi penetapan dan memberi perubahan mengenai beberapa ketentuan dalam KUHP, khususnya mengenai tindak pidana perjudian dalam KUHP merupakan suatu kejahatan mengenai apa yang diatur dalam Pasal 303 dan Pasal 303 bis, dimana bahwa dalam Pasal 1 Undang-Undang Nomor 7 Tahun 1974 menyatakan bahwa semua tindak pidana perjudian merupakan kejahatan. Pasal 303 KUHP merumuskan tindak pidana perjudian merupakan kejahatan, mengatur:

1) "Diancam dengan pidana penjara paling lama sepuluh tahun atau pidana denda paling banyak dua puluh lima juta rupiah, barang siapa tanpa mendapat izin:

1. dengan sengaja menawarkan atau memberikan kesempatan untuk permainan judi dan menjadikannya sebagai pencaharian, atau dengan sengaja turut serta dalam suatu kegiatan usaha itu;

2. dengan sengaja menawarkan atau memberi kesempatan kepada khalayak umum untuk bermain judi atau dengan sengaja turut serta dalam kegiatan usaha itu, dengan tidak peduli apakah untuk

19 Sagala, Mesias JP. "TINJAUAN YURIDIS TERHADAP TINDAK PIDANA PERMAINAN JUDI JACKPOT (Studi Kasus Putusan Nomor 45/Pid. B/2017/PN. MDN)." Jurnal Hukum Kaidah: Media Komunikasi dan Informasi Hukum dan Masyarakat 18, no. 3 (2019): 88-100.

20 Qamar, Samsul, and Tarmizi Tarmizi. "Penerapan Sanksi Pidana Terhadap Tindak Pidana Perjudian Melalui Sistem Elektronik Di Wilayah Kota Banda Aceh." Jurnal Ilmiah Mahasiswa Bidang Hukum Pidana 2, no. 1 (2018): 66-77. 
menggunakan kesempatan adanya sesuatu syarat atau dipenuhinya sesuatu tata cara;

3. menjadikan turut serta pada permainan judi sebagai pencaharian."

2) "kalau yang bersalah melakukan kejahatan tersebut dalam menjalankan pencahariannya, maka dapat dicabut haknya untuk menjalankan pencaharian itu."

3) "Yang disebut dengan permainan judi adalah tiap-tiap permainan, dimana pada umumnya kemungkinan mendapat untung bergantung pada keberuntungan belaka, juga karena pemainnya lebih terlatih atau lebih mahir. Di situ termasuk segala pertaruhan tentang keputusan perlombaan atau permainan lain-lainnya yang tidak diadakan antara mereka yang turut berlomba atau bermain, demikian juga segala pertaruhan lainnya."

Adapun oleh Pasal 303bis dirumuskan bahwa kejahatan mengenai perjudian diatur:

1) "Diancam dengan pidana penjara paling lama empat tahun atau pidana denda paling banyak sepuluh juta rupiah; (1) barang siapa menggunakan kesempatan main judi, yang diadakan dengan melanggar ketentuan Pasal 303; (2) barang siapa ikut serta main judi di jalan umum atau dipinggir jalan umum atau di tempat yang dapat dikunjungi umum, kecuali jika ada izin dari penguasa yang berwenang yang telah memberi izin untuk mengadakan perjudian itu."

2) "jika ketika melakukan pelanggaran belum lewat dua tahun sejak ada pemidanaan yang menjadi tetap karena salah satu dari pelanggaran ini, dapat dikenakan pidana penjara paling lama enam tahun atau pidana denda paling banyak lima belas juta rupiah."

Sebagaimana pengaturan Pasal 303 KUHP menunjukkan lima macamm kejahatan, yakni sesuatu mengenai perjudiian (hazardspel) pada ayat (1), lalu ayat (2) memberi dasar pemberatan pidana, dan menyempurnakan mengenai pengertian judi sebagai suatu permainan dalam ayat (1) oleh ayat (3). Perjudian sendiri menurut ayat (3) tadi didefinisikan sebagai atau setiap-setiap permainan, umumnya kemungkinkan berhasil/menang tergantung untung-untungan semata, dengan potensi menang semakin besar dikarenakan telah terlatih atau mahirnya si pemain. ${ }^{21}$ Kegiatan atau perbuatan tanpa izin menjadi unsur yang terkandung pula dalam lima macam kejahatan mengenai perjudian tersebut. Melekatnya sifat perbuatan melawan hukum pada lima macam kejahatan tersebut karena adanya unsur tanpa izin. Artinya dengan adanya izin dari pejabat atau instansi yang berwenang, maka tidak dapat dipidana perbuatan mana yang dirumuskan dalam rumusan tersebut serta perbuatan tersebut pula tidak lagi melawan hukum. ${ }^{22}$ Dimasukkannya oleh pembentuk undang-undang mengenai unsur tanpa izin, dimaksudkan agar pemerintah atau lembaga institusi terkait tetap dapat melakukan tugas pengaturan dan pengawasan terkait permainan judi.

Rumusan Pasal 303 KUHP dengan beberapa ayat-nya tersebut, memberikan gambaran mengenai perjudian, pertama, permainan dengan potensi untung

21 Sari, Ni Wayan Indah Purwita and Artadi, I Ketut. "Kinerja Kepolisian Dalam Upaya Pencegahan Dan Penanggulangan Tindak Pidana Perjudian Togel Di Wilayah Hukum Kepolisian Resort Gianyar". Jurnal Hukum Pidana Fakultas Hukum Universitas Udayana 03, no. 02 (2014): 3.

22 Munawar, Said. "KEBIJAKAN PENEGAKAN HUKUM PIDANA TERHADAP PERJUDIAN." WIDYA PRANATA HUKUM JURNAL 1, no. 1 (2019): 1-18. 
bergantung peruntungan atau nasib semata. Artinya, untung maupun rugi atau menang maupun kalah hanya berdasarkan keberuntungan atau secara kebetulan saja. Kedua, permainan dengan peluang memperoleh kemenangan atau untung yang sedikit maupun banyak sesuai keahlian dan/atau kecakapan yang membuat. Dua bentuk perjudian di atas, diperluas dalam dua macam pertaruhan. Pertama, semua wujud pertaruhan dimana tidak diselenggarakan oleh yang berlomba atau bermain mengenai keputusan perlombaan. Kedua, adalah perjudian, semua wujud pertaruhan baik bagaimanapun caranya serta dalam segalahal manapun, yang tidak ditetapkan berdasarkan kalimat, maupun yang tidak menetapkan rupa dari pertaruhan secara limitatif. Layaknya permainan-permainan kuis di televisi demi memperoleh hadiah merupakan pengertian perjudian juga jika melihat pasal ini. Namun, adanya izin dari pihak-pihak yang berwenang memberi izin membuat permainan kuis tersebut tidak dilarang sebagaimana permainan dalam pengertian perjudian.

Berdasarkan uraian tersebut diatas, unsur-unsur yang terkandung untuk dapat suatu perbuatan tersebut dikatakan sebagai suatu perjudian diantaranya, pertama, perbuatan yang dilakukan pada umumnya dalam bentuk permainan, dan perlombaan/pertandingan, yang semata-mata dilakukan untuk memperoleh kesenangan atau untuk mengisi waktu luang yang pada tujuannya untuk hiburan. Pada unsur ini pelaku hanya menonton atau orang yang juga taruhan terkait sesuatu yang dimainkan atau dilombakan dimana pelaku tersebut menjadi tidak wajib terlibat langsung dalam permainan. Unsur yang kedua adalah, perbuatan atau permainan yang dilakukan bersifat untung-untungan, artinya hasil yang diperoleh atau dimanangkan dalam suatu permainan hanya bergantung pada spekulatif/untunguntungan, namun tidak jarang pula kemenangan diperoleh karana kebiasaan maupun kemahiran pemain. Unsur terakhir yaitu suatu permainan tersebut disertakan pula taruhan. Apapun dapat dijadikan taruhan baik uang maupun barang berharga lainnya, menjadi unsur penting untuk menetukan suatu perbuatan tersebut dapat atau tidak sebagai perbuatan perjudian.

Unsur-unsur tersebut membawa segala bentuk aktivitas atau perbuatan yang dilingkupinya menjadi suatu bentuk judi. Pada Pasal 1 ayat (1) PP No.9 Tahun 1981 memberikan rincian mengenai permainan yang digolongkan sebagai judi, diantaranya perjudian Kasino yang terdiri dari beragam jenis, perjudian pada tempat-tempat keramaian yang juga terdiri dari beberapa macam, serta perjudian dengan alasanalasan serta dikecualikan karena alasannya. Rincian bentuk-bentuk perjudian atau permainan judi yang diatur berdasarkan PP No.9 Tahun 1981, tidak menyebutkan microtransaction pada game khususnya sistem gacha dan loot box dalam game sebagai suatu bentuk perjudian. Sistem gacha dan loot box dalam game sendiri baru dikenal padapada awal tahun 2000-an yang membuatnya menjadi sesuatu yang baru yang jelas belum diatur pada peraturan perundang-undangan yang ada.

Pesatnya perkembangan teknologi informasi berbanding lurus dengan evolusi bentuk kejahatan modern dari kejahatan konvensional, tidak terkeciali perjudian. Menjadi suatu hal yang wajar bahwa peraturan perundang-undangan yang ada di Indonesia belum memuat mengenai itu. Namun saat ini, dengan adanya UndangUndang No. 11 Tahun 2008 tentang Informasi dan Transaksi Elektronik sebagaimana telah diubah oleh Undang-Undang Nomor 19 Tahun 2016 tentang Perubahan Atas Undang-Undang No. 11 Tahun 2008 tentang Informasi dan Transaksi Elektronik (UU ITE) memberikan payung hukum dalam penegakan hukum tidak terkecuali terkait tindak pidana perjudian dengan jaringan internet atau virtual. UU ITE memberikan pengaturan terhadap kegiatan-kegiatan di dunia maya, meliputi pula perbuatan- 
perbuatan yang mengindikasikan adanya pelanggaran hukum maupun perbuatanperbutan dengan unsur pidana didalamnya. ${ }^{23}$

UU ITE dibentuk untuk mengantisipasi segala bentuk cyber crime yang melibatkan penggunaan teknologi informasi, berkesesuaian dengan semakin melonjaknya intensitas digitalisasi, konvergensi dan globalisasi yang berkelanjutan dari teknologi informasi, yang berpeluang disalahgunakan untuk melakukan tindak pidana. Selain itu, dalam konsiderannya disebutkan, Indonesia merupakan bagian dari masyarakat informai dunia, untuk itu pengaturan maupun infrastruktur hukum di tingkat nasional terkait pengelolaan informasi dan teknologi elektronik harus dibentuk agar mampu menopang pembangunan teknologi informasi dengan optimal, merata dan menyeluruh. Kegiatan yang dilakukan dalam instrument sistem elektronik, atau disebut cyber space, walaupun bersifat virtual, saat ini seiring perkembangan teknologi dan informasi kegiatan tersebut merupakan tindakan atau perbuatan hukum yang dianggap nyata. Disamping itu, subjek pelakunya harus dikualifikasikan sebagai orang yang telah melakukan perbuatan hukum secara nyata. Hukum konvensional yang ada sebelumnya secara ukuran dan kualifikasi tidak mampu menjangkau segala kegiatan di ruang virtual, karena ada beberapa unsur didalamnya yang tidak bisa didekati, yang membuat kegiatan di ruang virtual tersebut berada diluar pengaturan atau pemberlakuan hukum.

Microtransaction dalam game merupakan bentuk perbuatan hukum yang secara nyata telah terjadi dan mengandung unsur pidana. Perbuatan hukum yang mengandung unsur pidana serta perbuatan mana terjadi secara virtual ini kemudian menjadi ranah UU ITE dalam pengaturannya. Unsur perjudian pada microtransaction dalam game yang terjadi pada UU ITE mengenai perjudian diatur dalam Pasal 27 ayat (2) UU ITE diatur, "Setiap orang dengan sengaja dan tanpa hak mendistribusikan dan/atau mentranmisikan dan/atau membuat dapat diaksesnya infomasi elektronik dan/atau dokumen elektronik yang memiliki muatan perjudian". Sedangkan dalam Pasal 45 ayat (1) Undang-undang Nomor 11 tahun 2008 tentang Informasi dan Transaksi Elektronik disebutkan sanksinya yang berbunyi; "Setiap Orang yang memenuhi unsur sebagaimana dimaksud dalam Pasal 27 ayat (1), ayat (2), ayat (3), atau ayat (4) dipidana dengan pidana penjara paling lama 6 (enam) tahun dan/atau denda paling banyak Rp1.000.000.000,00 (satu miliar rupiah)".

Berdasarkan uraian diatas, perjudian adalah tindakan pidana yang diatur pada KUHP Pasal 303 dan Pasal 27 ayat (2) UU ITE. Pada kedua aturan mengenai tindak pidana perjudian tersebut memiliki kesamaan subyek hukum yaitu orang perorangan maupun badan/perusahaan. Mengenai obyek hukum pun tidak berbeda yakni tindak pidana perjudian. Jika melihat pada microtransaction gacha dan loot box dalam game, ada unsur perbuatan tersebut dilakukan secara virtual, yang memposisikan UU ITE sebagai lex specialis dari perbuatan hukum diatas dan 303 KUHP menjadi lex generalis. Sehingga terhadap tindak pidana perjudian pada microtransaction gacha dan loot box dalam game dapat dikenakan sanksi pidana sebagaimana yang diatur dalam UU ITE.

23 Sulistyo, Hery, and Lindu Ardjayeng. "TINJAUAN YURIDIS TENTANG PERJUDIAN ONLINE DITINJAU DARI UNDANG-UNDANG NO 11 TAHUN 2008 TENTANG INFORMASI DAN TRANSAKSI ELEKTRONIK." Dinamika Hukum \& Masyarakat 1, no. 1 (2020). 


\subsection{Pertanggungjawaban Pidana oleh Korporasi sebagai Penyedia Layanan Perjudian Micro-transaction Dalam Game}

Pada mulanya Korporasi dipandang belum selaku subyek hukum pidana, karena KUHP cuma mengidentifikasi orang perorangan sebagai subyek hukum pidana. Sampai akhirnya, peraturan perundang-undangan lain seperti Undang-Undang Daruratt No7 Tahun 1955 tentang Pengusutan, Penuntutan dan Peradilan Tindak Pidana Ekonomi, lalu Undang-undang no. 9 Tahun 1985 jo. undang-undang No. 31 tahun 2004 tentang perikanan, lalu Undang-undang No. 31 Tahun 1999 jo. UndangUndang No.20 Tahun 2001 tentang Pemberantasan Tindak Pidana Korupsi, lalu undang-undang No.8 tahun 2010 tentang pencegahan dan Pemberantasan Tindak Pidana Pencucian Uang, Undang-undang No.35 Tahun 2009 tentang Narkotika, undang-undang No.8 tahun 1999 tentang perlindungan Konsumen, Undang-Undang No.21 tahun 2001 tentang minyak dan gas bumi, kemudian undang-undang No.30 tahun 2009 tentang ketenagalistrikan, lalu Undang-undang No.32 tahun 2009 tentang Perlindungan dan Pengelolaan Lingkungan Hidup, Undang-undang No.41 tahun 1999 tentang kehutanan, undang-undang No.4 tahun 2009 tentang mineral dan pertambangan batubara dan lain-lain, yang menentukan bahwa korporasi sudah menjadi subyek hukum pidana.

Korporasi menjadi subyek hukum pidana diakui secara mendunia, melalui adanya konferrensi Internasional ke empat belas tentang Ciminal Liability of Corporation yang diselenggarakan di Atena pada tahun 1994, yang dilatarbelakangi oleh sejarah serta beraneka ragam pengalaman dari tiap negara termasuk Indonesia, dengan kesamaan pandangan bahwa tidak saja manusia(natural person) yang merupakan subyek hukum pidana namun meliputi pula korporasi. ${ }^{24}$ Eksistensi korporasi memberikan pengaruh besar terhadap pembangunan suatu negara,mengingat begitu pesatnya perkembangan dan pertumbungan ekonomi, teknologi dan informasi saat ini, yang berbanding lurus dengan potensinya menyelenggarakan penyimpangan atas perbuatan yang dilakukan oleh korporasi yang bermuara pada tindak pidana.

Korporasi dalam Bahasa belanda, "corporatie", dalam Bahasa Inggris "corporation", yang keduanya istilah tersebut berasal dari kata "corporare", dan corporare ini berasal dari kata "corpus", yang diartikan dalam Bahasa Indonesia menjadi badan atau memberikan badan atau membadankan, yang kemudian menurut Utrecht dan dikutip Moh. Saleh Djindang, bahwa "korporasi adalah suatu gabungan orang yang dalam pergaulan hukum bertindak bersama-sama sebagai subyek hukum tersendiri suatu personafikasi". ${ }^{25}$ Berdasarkan pengertian tersebut, dapat dikatakan korporasi merupakan wujud badan hukum dengan memiliki anggota, tetapi terdapat pemisahan terkait hak dan kewajiban antara badan dengan masing-masing anggotanya. Korporasi pada prinsipnya sebagai Legal personality, diartikan bahwa korporasi mempunyai harta kekayaan sendiri selayaknya manusia yang serta merta dapat dituntut secara perdata, tetapi dalam perkembangannya timbul memikiran untuk korporasi dapat bertanggungjawab secara pidana meski pidana yang dikenakan pada korporasi berupa pidana denda atau tindakan lain berupa tata tertib atau

24 Ratomi, Achmad. "Korporasi Sebagai Pelaku Tindak Pidana (Suatu Pembaharuan Hukum Pidana Dalam Menghadapi Arus Globalisasi Dan Industri)." Al-Adl: Jurnal Hukum 10, no. 1 (2018): 1-22.

25 Krismen, Yudi. "Pertanggungjawaban Pidana Korporasi Dalam Kejahatan Ekonomi." Jurnal Ilmu Hukum 5, no. 1 (2014): 61-70. 
tindakan administratif. ${ }^{26}$ Di Indonesia sendiri, sistem subyek hukum pidana tidak disamakan berdasarkan yang berbuat tindak pidana dan yang wajib mempertanggungjawabkan.

Pemidanaan yang dikenakan kepada korporasi tidaklah sama dengan pemidanaan yang dijatuhkan pada orang perorangan selaku subyek hukum pidana, hal itu karena korporasi memiliki karakter tersendiri yang secara prinsip berbeda dengan orang perorangan. Terkait sanksi pidana-nya pun tidak semuanya dapat dikenakan pada korporasi layaknya diterapkan pada orang perorangan, misalnya pidana mati atau pidana penjara. Sehingga diperlukan sanksi pidana yang sesuai untuk diterapkan kepada korporasi. Melihat sisi kemanfaatan dari pemidanaan yang dijatuhkan kepada korporasi menjadi sesuatu hal yang penting, mengingat sanksi tidak saja menjadi bentuk pertanggungjawaban korporasi itu sendiri, namun jauh dari pada itu harus dilihat pula pada kepentingan-kepentingan masyarakat secara luas. Dengan demikian maka sanksi pidana yang sesuai untuk dikenakan pada korporasi yang perbuatan pidana adalah berupa sanksi percobaaan (probation), sanksi denda (equity fine), atau dialihkan berbentuk sanksi tambahan, sanksi individu,sanksi pelayanan masyarakat (community service), kewenangan yuridiis pihak luar perusahaan serta kewajiban membeli saham. Identifikasi terhadap pertanggungjawaban korporasi oleh Steven Box digolongkan dalam ruang lingkup kejahatan korporasi diantaranya, pertama, crimes for corporation artinya pelanggaran hukum dilakukan korporasi demi tujuannya meraih profit sebanyak-banyaknya, kedua, criminal corporation atau diartikan bahwa kejahatan memang menjadi tujuan utama suatu korporasi, dan ketiga, crime against corporations atau jika digambarkan pada posisi ini korporasi sebagai korban, karena adanya pencurian, penipuan atau penggelapan terhadap milik korporasi. ${ }^{27}$

Mengenai microtransaction dalam suatu game tentunya ada juga dua pihak disini yaitu para pemain yang melakukan microtransaction tersebut dan pihak publisher dan/atau developer game tertentu yang menyediakan sarana microtransaction yang mengandung unsur perjudian di dalam game yang dibuat atau dipasarkan. Publisher dan developer game sebenarnya tidak dapat disamakan, developer adalah orang atau kumpulan orang yang membuat game dan publisher sendiri adalah perusahaan yang menyokong dana dalam usaha developer game dalam membuat game. Namun, tidak jarang juga suatu publisher memiliki bagian developer game sendiri dalam perusahaannya dan juga developer game tidak jarang jika mereka memodalkan dengan uang sendiri dalam membuat suatu game. Dengan demikian, suatu unsur perjudian dalam suatu game baik itu perjudian dalam sistem microtransaction dalam bentuk gacha dan/atau lootbox, maka publisher dan/atau developer game inilah yang bertanggungjawab. Kaitannya dalam hukum pidana, tentu yang menjadi subyek pidana disini adalah perusahaan publisher dan/atau developer game yang bersangkutan atau bisa dikatakan tindak pidana korporasi.

Mardjono Reksodiputro mengatakan, wujud korporasi melakukan pertanggungjawaban pidana ada 3 diantaranya, pengurus korporasi selaku yang membuat serta bertanggungjawab, korporasi selaku subyek hukum diakui sudah

26 Situmorang, Jegesson P., and Ameik Soemarmi Pujiyono. "Pertanggungjawaban pidana korporasi dalam menanggulangi tindak pidana perikanan." Diponegoro Law Journal 5, no. 3 (2016): 1-17.

27 Anjari, Warih. "Pertanggungjawaban Korporasi Sebagai Pelaku Tindak Pidana." E-Journal Widya Yustisia 1, no. 2 (2017). 
mampu melakukan perbuatan pidana tetapi pertanggungjawabannya dibebankan kepada pengurus, dan korporasi sebagai subyek hukum karenanya diaggap sebagai pembuat dan terhadapnya dapat dimintai pertanggungjabawan. ${ }^{28}$ Pandangan tersebut mengarahkan bahwa suatu korporasi jika memenuhi unsur melakukan suatu tindak pidana maka korporasi tersebut dapat melakukan pertanggungjawaban, atau beban pertanggungjawaban pidana-nya dipikul oleh pengurus korporasi.

Pada UU ITE mengenai ketentuan pidana diatur dalam Pasal 45 sampai dengan Pasal 52. Pasal-pasal UU ITE yang mengautur mengenai ketentuan pidana diidentifikasikan bahwa subyek atau yang berbuat tindakan pidana bisa dituntut pertanggungjawaban pidana yakni 'setiap orang' yaitu orang perorangan juga korporasi. Disamping pula diawal UU ITE ini pada ketentuan umum Bab I, bahwa "orang adalah orang perorangan, warga negara Indonesia atau warga negara asing, maupun badan hukum sedangkan badan usaha adalah perusahaan perorangan atau perusahaan persekutuan, baik berbadan hukum maupun tidak berbadan hokum". Rumusan ini memperlihatkan jika korporasi menjadi subyek hukum pula dalam UU ITE. Dengan demikian dapat dimintakan pertanggungjawaban pidana pada korporasi bilamana terbukti korporasi berbuat tindak pidana.

Berkaitan dengan syarat-syarat pertanggungjawaban pidana yang dikenakan pada korporasi sudah diatur dalam UU ITE, dimana korporasi yang melaksanakan kegiatan sebagaimana diatur pada Pasal 27 hingga Pasal 37. Mengenai pertanggungjawaban pidana bagi korporasi telah pula diatur menyangkut para pihak yang dimungkinkan ditagih pertanggungjawaban pidana berkaitan dengan ternyadinya kejahatan korporasi (criminal corporation) sebagaimana diuraikan pada penjelasan ayat (4) Pasal 52 UU ITE, dijelaskan ancaman pidana sesuai dengan yang dirumuskan Pasal 52 ayat (4) adalah bertujuan menghukum perbuatan-perbuatan yang sesuai dengan apa yang diatur Pasal 27 sampai dengan Pasal 37 dimana perbuatan melawan hukum dimaksud dilakukan korporasi dan/atau pengurus dan/atau staf yang mempunyai wewenang diantaranya; "mewakili korporasi; mengambil keputusan dalam korporasi; melakukan pengawasan serta pengendalian dalam korporasi; dan melakukan kegiatan demi keuntungan korporasi".

UU ITE ini terlihat menganut ajaran identifikasi (doctrine of identification), yaitu teori atau doktrin yang memberikan pembenaran mengenai korporasi yang dibebankan pertanggungjawaban pidana. ${ }^{29}$ Walaupun pada kenyataannya korporasi tidak seperti halnya orang perorangan (manusia), sebagaimana adagium "actus non facit reum, nisi mens sit rea" atau tidak ada pidana tanpa kesalahan, dimana umumnya suatu kesalahan hanya bisa dilakukan oleh yang memiliki perasaan atau niat. UU ITE memberikan pengawasan yang lebih spesifik terkait beberapa perbuatan yang digolongkan sebagai suatu tindak pidana. Semakin berkembangnya perkembangan teknologi, memberikan peluang suatu perjudian terjadi melalui vitual. Sebagaimana yang terjadi pada sistem microtransaction dalam suatu game yang tentunya memberikan kerugian bagi para pelakunya dan tentunya UU ITE ini memberikan keleluasaan untuk aparat penegak hukum untuk dapat menegakkan hukum terkait

28 Reza, Aulia Ali. "Pertanggungjawaban Korporasi dalam Rancangan KUHP." Institute for Criminal Justice Reform, Jakarta Selatan (2015).

29 Mulasari, Laila. "Ajaran Pertanggungjawaban Pidana Korporasi Dalam Kebijakan Hukum Pidana Di Bidang Mayantara." Jurnal Ilmiah Hukum dan Dinamika Masyarakat 9, no. 2 (2016). 
tindak pidana yang terjadi dalam dunia virtual yang terhubung melalui jaringan internet.

Pada prinsifnya, siapapun yang membuat, memfasilitasi maupun mengembangkan sesuatu hal dalam bentuk apapun yang memenuhi unsur perjudian dapat diancam pidana sebagaimana diatur dalam pasal yang bersangkutan. Pembuat sistem tersebut dapat dianggap telah memberikan/ memfasilitasi permainan judi, serta dapat dianggap turut serta dalam suatu perusahaan yang melakukan perjudian. Microtransaction dalam suatu game gacha dan loot box merupakan suatu bentuk sistem transaksi baru yang memenuhi unsur perjudian, sehingga penegak hukum dapat bertindak terkait hal tersebut berdasarkan pada UU ITE. Namun disamping itu, penting rasanya jika dibarengi dengan adanya lembaga ataupun komisi yang mengawasi hal tersebut. Indonesia saat ini tidak memiliki lembaga atau komisi yang bertugas mengawasi mengenai perjudian dan juga lembaga atau komisi yang secara khusus bertugas mengawasi mengenai game-game yang beredar di Indonesia.

Penting rasanya pemerintah memperhatikan hal tersebut karena melirik kondisi sekarang dimana ilmu pengetahuan dan teknologi mengalami perkembangan pesat dan tentunya perkembangan tersebut harus tetap dikawal dengan suatu regulasi maupun lembaga-lembaga khusus yang mengawasi hal tersebut. Untuk dapat dijembatani atau dibatasi segala kepentingan-kepentingan yang muncul baik itu dari pihak pemain game maupun pihak menyedia game (developer). Agar kemudian tidak terjadi tindakan-tindakan yang merugikan pihak satu sama lain atau bahkan merugikan masyarakat suatu bangsa. Dengan adanya pengawasan dari lembaga khusus, maka segala kepentingan yang menimbulkan kerugian bagi pihak lain dapat diminimalisir dan esensi dari suatu game sebagai suatu media hiburan bagi masyarakat dapat tetap terjaga tanpa menimbulkan hal-hal negatif kedepannya.

\section{Kesimpulan}

Microtransaction dalam game baik dalam bentuk gacha atau lootbox adalah permainan dan sesuatu transaksi yang bergantung pada untung-untungan yang mengandung unsur perjudian, dimana delik perjudian sendiri diatur dalam KUHP dan Undang-undang Penertiban Perjudian serta melalui Peraturan Pemerintah tentang Pelaksanaan Penertiban Perjudian. Disamping itu karena perjudian dilakukan dengan media internet secara virtual maka dapat digunakan Undang-undang Informasi dan Transaksi Elektronik sebagai payung hukum dalam penegakan hukum perjudian yang dilakukan secara virtual. Sehingga terhadap tindak pidana perjudian pada microtransaction gacha dan loot box dalam game dapat dikenakan sanksi pidana sebagaimana yang diatur dalam UU ITE. Publisher dan/atau developer game merupakan Korporasi yang juga sebagai subyek hukum pidana dan menjadi pihak yang menyediakan sarana perjudian dengan bentuk Microtransaction dalam game baik berupa gacha dan loot box, sehingga atas hal tersebut Publisher dan/atau developer game dapat dimintai pertanggungjawaban pidana.

\section{DAFTAR PUSTAKA}

\section{Buku :}

Diantha, I.M.P. Metode Penelitian Hukum Normatif Dalam Justifikasi Teori Hukum (Jakarta, Prenada Media Group, 2017), 1.

Marzuki, Peter Mahmud. Penelitian Hukum (Jakarta, Prenada Media Group, 2014), 133. 
West, Michael, An International Reader's Dictionaty, (London, Longman Group Limited, 1970) 155.

\section{Jurnal :}

Adnyana, Komang Wisnu, Putu Sugi Ardana, and I. Nyoman Lemes. "PEMIDANAAN TERHADAP PELAKU PERJUDIAN YANG DILAKUKAN ANAK-ANAK (STUDI KASUS DI PENGADILAN NEGERI SINGARAJA)." Kertha Widya 2, no. 2 (2019).

Anjari, Warih. "Pertanggungjawaban Korporasi Sebagai Pelaku Tindak Pidana." EJournal Widya Yustisia 1, no. 2 (2017).

ARIEF, MOH ZAINOL, and SUTRISNI SUTRISNI. "Perbuatan Melawan Hukum dalam Transaksi Jual-beli melalui Internet Ditinjau dari Buku III Kuhperdata." Jendela Hukum 1, no. 2 (2014): 135649.

Garvin, Garvin, Jennifer Claudia, and Irene Evita. "MICRO TRANSACTION DALAM ONLINE GAME: APAKAH MEMICU PERILAKU BELANJA ONLINE YANG BERMASALAH?." PSYCHE: Jurnal Psikologi 1, no. 2 (2019): 46-54.

Haryadi, Wahyu Tris. "PENEGAKAN HUKUM JUDI ONLINE BERDASARKAN PENERAPAN KUHP DAN UNDANG UNDANG NO. 19 TAHUN 2016 TENTANG PERUBAHAN ATAS UNDANG-UNDANG NO. 11 TAHUN 2008 TENTANG INFORMASI DAN TRANSAKSI ELEKTRONIK." Jurnal Hukum Inrichting Recht Wahana Wacana Bidang Hukum 13, no. 2 (2019): 119-133.

Indahtiningrum, Fitriana. "Hubungan antara kecanduan video game dengan stres pada mahasiswa Universitas Surabaya." Calyptra 2, no. 1 (2013): 1-17.

Isnaini, Enik. "TINJAUAN YURIDIS NORMATIF PERJUDIAN ONLINE MENURUT HUKUM POSITIF DI INDONESIA." Jurnal Independent 5, no. 1 (2017): 23-32.

Krismen, Yudi. "Pertanggungjawaban Pidana Korporasi Dalam Kejahatan Ekonomi." Jurnal Ilmu Hukum 5, no. 1 (2014): 61-70.

Manalu, Hendri Saputra. "Penegakan Hukum Terhadap Pelaku Tindak Pidana Perjudian Online." Journal of Education, Humaniora and Social Sciences (JEHSS) 2, no. 2 (2019): 428-539.

Mulasari, Laila. "Ajaran Pertanggungjawaban Pidana Korporasi Dalam Kebijakan Hukum Pidana Di Bidang Mayantara." Jurnal Ilmiah Hukum dan Dinamika Masyarakat 9, no. 2 (2016).

Munawar, Said. "KEBIJAKAN PENEGAKAN HUKUM PIDANA TERHADAP PERJUDIAN." WIDYA PRANATA HUKUM JURNAL 1, no. 1 (2019): 1-18.

Qamar, Samsul, and Tarmizi Tarmizi. "Penerapan Sanksi Pidana Terhadap Tindak Pidana Perjudian Melalui Sistem Elektronik Di Wilayah Kota Banda Aceh." Jurnal Ilmiah Mahasiswa Bidang Hukum Pidana 2, no. 1 (2018): 66-77.

Ratomi, Achmad. "Korporasi Sebagai Pelaku Tindak Pidana (Suatu Pembaharuan Hukum Pidana Dalam Menghadapi Arus Globalisasi Dan Industri)." Al-Adl: Jurnal Hukum 10, no. 1 (2018): 1-22.

Reza, Aulia Ali. "Pertanggungjawaban Korporasi dalam Rancangan KUHP." Institute for Criminal Justice Reform, Jakarta Selatan (2015).

Sagala, Mesias JP. "TINJAUAN YURIDIS TERHADAP TINDAK PIDANA PERMAINAN JUDI JACKPOT (Studi Kasus Putusan Nomor 45/Pid. B/2017/PN. MDN)." Jurnal Hukum Kaidah: Media Komunikasi dan Informasi Hukum dan Masyarakat 18, no. 3 (2019): 88-100. 
Santoso, Eddy, and Sri Endah Wahyuningsih. "Peran Kepolisian Dalam Sistem Peradilan Pidana Terpadu Terhadap Penanggulangan Tindak Pidana Perjudian." Jurnal Daulat Hukum 1, no. 1 (2018).

Sari, Ni Wayan Indah Purwita and Artadi, I Ketut. "Kinerja Kepolisian Dalam Upaya Pencegahan Dan Penanggulangan Tindak Pidana Perjudian Togel Di Wilayah Hukum Kepolisian Resort Gianyar". Jurnal Hukum Pidana Fakultas Hukum Universitas Udayana 03, no. 02 (2014): 3.

Situmorang, Jegesson P., and Ameik Soemarmi Pujiyono. "Pertanggungjawaban pidana korporasi dalam menanggulangi tindak pidana perikanan." Diponegoro Law Journal 5, no. 3 (2016): 1-17.

Suangga, Anisa. "Hubungan Aktivitas Bermain Video Game dengan School Myopia pada Siswa-Siswi SD Asy Syifa 1 Bandung." Students e-Journal 1, no. 1 (2012): 36.

Sulistyo, Hery, and Lindu Ardjayeng. "TINJAUAN YURIDIS TENTANG PERJUDIAN ONLINE DITINJAU DARI UNDANG-UNDANG NO 11 TAHUN 2008 TENTANG INFORMASI DAN TRANSAKSI ELEKTRONIK." Dinamika Hukum $\mathcal{E}$ Masyarakat 1, no. 1 (2020).

Tuwo, Christy Prisilia Constantia. "Penerapan Pasal 303 Kitab Undang-undang Hukum Pidana Tentang Perjudian." Lex Crimen 5, no. 1 (2016).

Waney, Geraldy. "Kajian Hukum terhadap Tindak Pidana Perjudian (Penerapan Pasal 303, 303 Bis Kuhp)." Lex Crimen 5, no. 3 (2016).

\section{Berita, Website:}

Heri Susanto, (2020). Menohok! Pengacara Prancis Gugat Game FIFA 20, Kenapa? Vivagoal, diakses pada 3 Maret 2020, pukul 09.45 WITA.

Lexico, https://www.lexico.com/en/definition/video_game. Diakses pada 20 Pebruari 2020.

Kompas.com, Cerita Ibu di Kediri Kaget Dapat Tagihan Game Online Rp. 11 Juta,https://regional.kompas.com/read/2019/04/10/12362821/cerita-ibu-dikediri-kaget-dapat-tagihan-game-online-rp-11-juta. Diakses pada tanggal 12 Pebruari 2020.

Tempo.co, Dapat Tagihan Game Online Rp. 65 Juta, Inul Daratista Kejang, https://www.msn.com/id-id/hiburan/celebrity/dapat-tagihan-game-online-

rp-65-juta-inul-daratista-kejang/ar-BBXMUhf. Diakses pada tanggal 12 Pebruari 2020.

\section{Perundang-Undangan :}

Kitab Undang-Undang Hukum Perdata

Kitab Undang-Undang Hukum Pidana

Undang-Undang Republik Indonesia Nomor 39 Tahun 1999 Tentang Hak Asasi Manusia

Undang-Undang Nomor 7 tahun 1974 Tentang Penertiban Perjudian

Undang-Undang Nomor 11 Tahun 2008 Tentang Informasi dan Transaksi Elektronik

Undang-Undang Nomor 19 Tahun 2016 Tentang Perubahan Atas Undang-Undang No.

11 Tahun 2008 tentang Informasi dan Transaksi Elektronik

Undang-Undang Nomor 35 tahun 2014 tentang Perubahan Atas Undang-Undang Nomor 23 tahun 2002 Tentang Perlindungan Anak

Peraturan Pemerintah Nomor 9 Tahun 1981 Tentang Pelaksanaan Penertiban Perjudian 